Egypt. Acad. J. Biolog. Sci., 12(2):67-74 (2020)

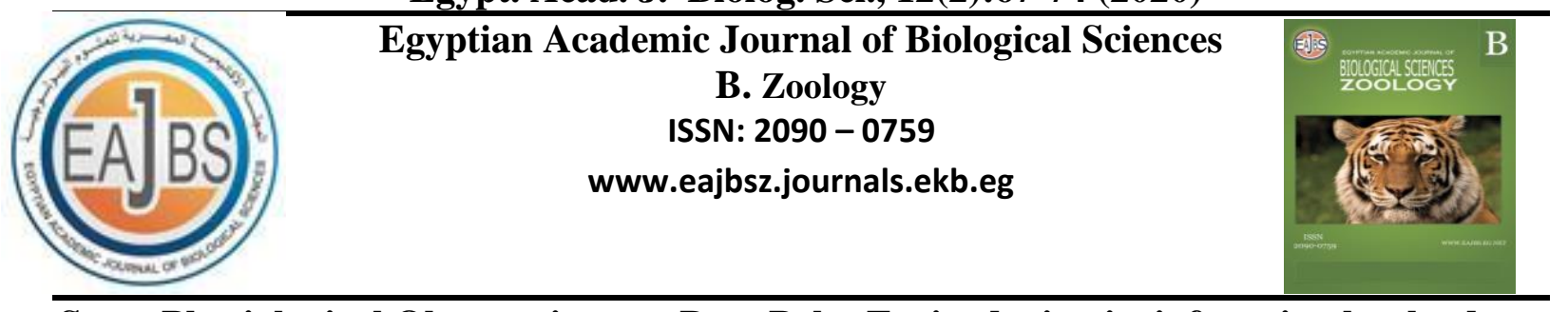

Some Physiological Observations on Date Palm Fruits during its infestation by the date palm dust mite, Oligonychus afrasiaticus (McGregor)

\title{
(Acari: Tetranychidae)
}

\author{
Rania H. Mahmoud ${ }^{1}$, E.M.A. Yassin ${ }^{1}$ and El-Shafei , W.K.M. ${ }^{2}$ \\ 1-Plant Prot. Res. Inst., Agricultural Research Center ARC, Giza, Egypt. \\ 2- Dep. of Date Palm Pests and Diseases, Central Lab. for Date Palm, Agricultural Research \\ Centre ARC, Giza, Egypt. \\ E.Mail.: waelkamal27@yahoo.com
}

\begin{abstract}
ARTICLE INFO
Article History

Received: 5/ 7/2020

Accepted: $16 / 9 / 2020$
\end{abstract}

Keywords:

Oligonychus

afrasiaticus

(McGregor), Date

Palm fruits,

Physiological

Observations, proteins, carbohydrates

\section{ABSTRACT}

The current study aimed to survey the phytophagous tetranychid mite, Oligonychus afrasiaticus (McGregor) Tetranychidae in different regions of Egypt. Also, the effect of $O$. afrasiaticus infestation on the different components of date palm fruits was determined after one month of filed infestation. The results showed that the $O$. afrasiaticus appeared infested the date palm fruits in New -Valley, Giza, and Marsa Matruh Governorates only and disappeared from the other tested locations of Egypt. It was observed from the study that $O$. afrasiaticus infested Barhi Variety (Fresh) with a rare number in Sharq El-Ewinate region (New -Valley) only. On the other hand, Siwi variety (Semi-dry) infested with $O$. afrasiaticus on date palm fruits in Baharia Oasis (Giza Governorate), Siwa Oasis region (Marsa Matruh), El-Kharga Oasis and Dakhla Oasis region (New -Valley ). However, it was noticed that Samani and Zaghloul (Fresh varieties) did not infest with $O$. afrasiaticus during this study. The current study indicated that the protein contents were decreased when the fruits exposed to the infestation by O. afrasiaticus where it was recorded $18.6 \mathrm{mg} / \mathrm{gm}$ of fruits in infested fruits compared to $26.37 \mathrm{mg} / \mathrm{gm}$ in non-infested fruits. The highest level of carbohydrate content was (445.0 $\mathrm{mg} / \mathrm{gm}$ ) in non-infested date palm fruits. While the lowest carbohydrates level $(308.0 \mathrm{mg} / \mathrm{gm})$ was found when the date fruits exposed to mite's infestation. The obtained data showed that the nitrogen content of infested date palm fruits was $3.33 \mathrm{ug} / \mathrm{gm}$ of fruits but the recorded level of nitrogen in non-infested fruits was $4.37 \mathrm{ug} / \mathrm{gm}$ of fruits. The lowest content of phosphorus $(3.1 \mu \mathrm{g} / \mathrm{gm})$ was observed with infested fruits compared with $7.43 \mu \mathrm{g} / \mathrm{gm}$ in the case of noninfested fruits. There were slight differences in potassium contents(7.16 and $7.83 \mu \mathrm{g} / \mathrm{gm}$ ) between infested and non-infested date fruits respectively,.The biochemical data revealed that the level of calcium contents was slightly differed (16.4 and $16.67 \mu \mathrm{g} / \mathrm{gm})$ in date palm fruits infested and non-infested with mite individuals of $O$. afrasiaticus, respectively.

\section{INTRODUCTION}

The date palm, Phoenix dactylifera L. (Arecaceae) is known as one of the fruits that have been cultivated in the Middle East and North Africa thousands of years ago (El Hadrami and El Hadrami 2009). The production of date in the Arabian Peninsula and the Middle East 
has increased and expected to increase more (Chao and Krueger 2007). The date palm fruits are of high energy fruit with numerous medical, social, food, and industrial values (ElHalawany et al., 2017). About 55 cultivars of date palm fruits are commercially produced in Egypt '(Bekheet and El-Sharabasy, 2015). Date palms are attacked by many insect and mite pests (El-Shafie et al., 2017) which varied according to cultivar, location, weather, and cultural practices. Pests are a serious threat to date palm plantations, causing great economic loss to the growers in Egypt. They reduce about $52 \%$ of the total yield (Central Administration for Agricultural Extension Services, Egypt, 2001). The susceptibility of date palm fruits to harmful mite's infestation was worldwide distribution. The phytophagous harmful mites belong to genus Oligonychus(Acari: Tetranychidae) especially, the old world date mite, $O$. afrasiaticus (McGregor) are known to occur in most date palm growing areas in the world(Basshaih 1999, Ben Chaaban et al. (2017), El-Halawany et al. (2001), Elwan, 2000, Talhouk (1991).The distribution variance of this pest seems to be a phenomenon occurring everywhere independent of climatically or geographical zones and often related to changes in the chemical composition of dates (Ben Chaaban and Chermiti, 2009). These mites can cause very serious damage to fruits (size, weight, sugars, moisture contents, and acid activity) (ElHalawany et al., 2017). In the USA, there is direct damage caused by the mite $O$. pratensis Banks on immature green date fruit (making a hole in cells and sucking the juice from the surface of the fruit). (Mauk et al., 2005).There were Many important compounds in the date fruits. Flavonoides, P-Coumaric acid, and Procyanidins (Rahmani et al., 2014); diosmetin 7O-B-D- apiofuranoside and diosnetin 7 O-B-L-arabinofuransyl (Michael et al., 2013). Due to these bioactive compounds, the date fruits have many benefits such as antioxidant, antidiabetic, antimicrobial, and anti-inflammatory activity (Ragab et al., 2013); (Rahmani et al., 2014); (Michael et al., 2013). El-Sohaimy and Hafez (2010) demonstrated that the date palm extract contains $13.80 \%$ moisture and $86.50 \%$ total solid. Also contains, Ash and Crud fibers contents were 2.13 and 5.20 respectively. These data revealed that, the date palm containing the most of essential nutritional matters which are necessary to human activities and saving their life (El-Sohaimy and Hafez 2010). In the current study, the surveying of the phytophagous mite, $O$. afrasiaticus in different regions of Egypt was studied. Also, the effect of $O$. afrasiaticus infestation on the different components of date palm fruits was determined after one month of filed infestation.

\section{MATERIALS AND METHODS}

\section{Survey Study:}

A survey was conducted during May-August 2018 and 2019 in El-Menofia, El-Behira, El-Sharkia, Giza, and New-valley Governorates. The survey covered different common date palm varieties plantation in the tested regions. Date fruits samples were collected about one kilogram for each sample. Three samples were collected randomized from each tested field, whether infested with the mite or not infested (control). The inspection focused on dust mite infestation symptoms. Heavily silk webbing on bunches was a primer sigh on the occurrence of the dust mites, Sanad et al., (2017). Samples were transferred to the laboratory for examination using a binocular microscope.

The date palm fruits (which already infested with the dust mite (about one month), Fig.(1), and non-infested ones, Fig. (2) were transferred to the Laboratory of Insect Pest Physiology. Plant Protecting Research Institute, for Biochemical analysis of different fruit components (Carbohydrates, Proteins, Phosphorus, Nitrogen, Potassium, and Calcium). 


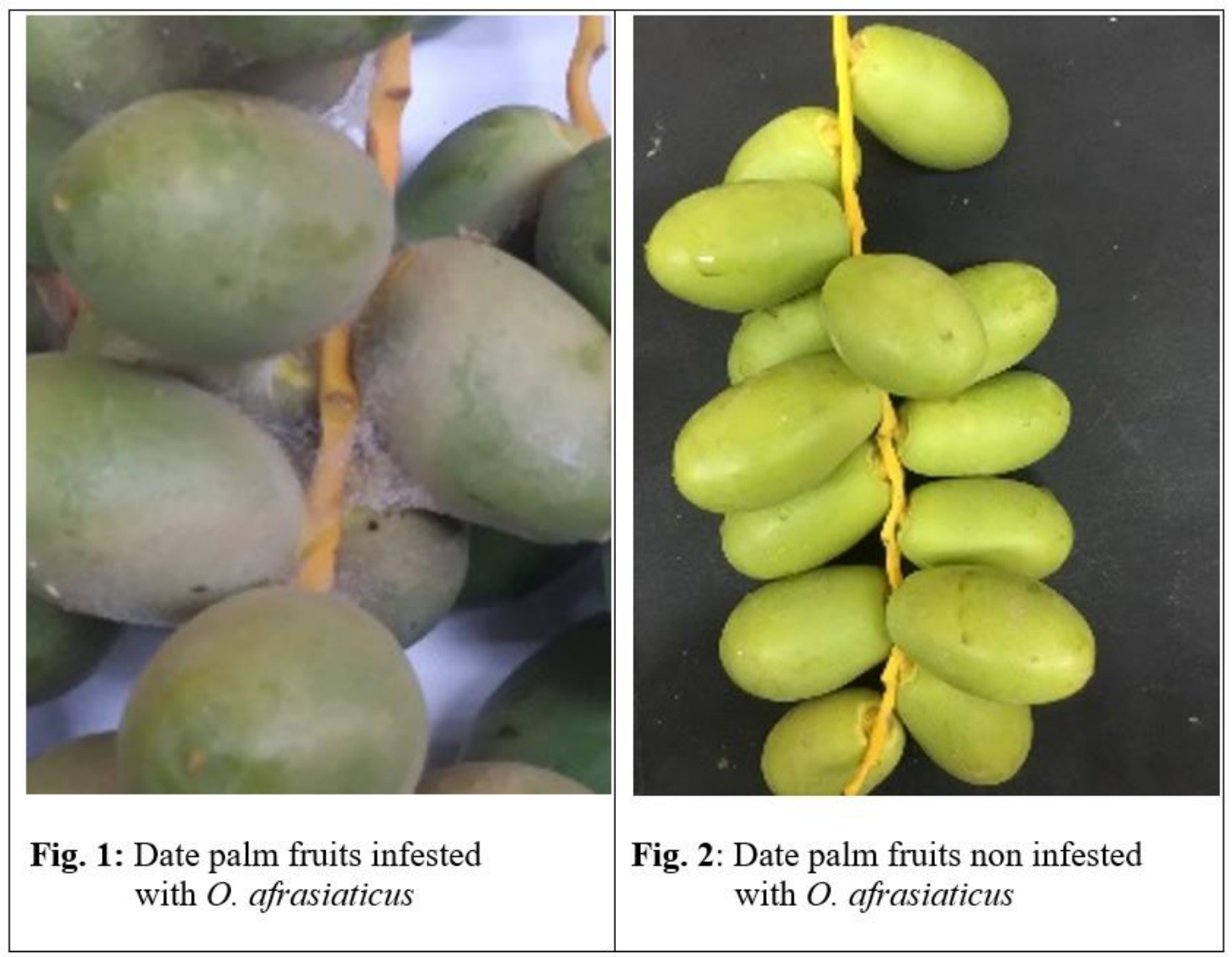

\section{Carbohydrates:}

Weight $100 \mathrm{mg}$ of the plant sample into a boiling tube. Hydrolyse by keeping it in a boiling water bath for three hours after adding $10 \mathrm{ml}$ of $2.5 \mathrm{~N} \mathrm{HCl}$, and cool at room temp. Neutralize it with sodium carbonate until effervescence. Centrifuge and collect the supernatant for analysis.

Total carbohydrates were estimated in the acid extract of the sample by the phenol-sulphuric acid reaction of Dubois et al. (1956). Total carbohydrates were determined for assay as described by Crompton and Birt (1967). Sample (1 gm) was homogenized in 0.3N HClO4(5 $\mathrm{ml}$ ) at $0^{\circ} \mathrm{C}$ for $1 \mathrm{~min}$. The three supernatant combined into the acid extract. Hundred micro liters of the acid extract was added into a colorimetric tube to $0.5 \mathrm{ml}$ of phenol (20 percent $\mathrm{w} / \mathrm{v})$. Then added $5 \mathrm{ml}$ of concentrated sulfuric acid. The tubes were standing $10 \mathrm{~min}$, then they were shaken and placed for $10-20 \mathrm{~min}$ in a water bath at 25 to $30{ }^{\circ} \mathrm{C}$ before readings. Blanks were prepared for the sugar solution. The absorbance of characteristic yellow-orange color is measured at $490 \mathrm{~nm}$ compared with blank. Total carbohydrate unit: $\mu \mathrm{g}$ glucose/gm fresh weight.

\section{Total Proteins:}

As described by Bradford (1976) Weight $500 \mathrm{mg}$ of the plant sample grind well with a pestle and mortar in $5 \mathrm{ml}$ of $0.01 \mathrm{ml}$ phosphate buffer $(\mathrm{pH} 7$ ). Protein reagent was prepared by dissolving $100 \mathrm{mg}$ of Coomassie Brilliant Blue G-250 in $50 \mathrm{ml} 95 \%$ ethanol. Then $100 \mathrm{ml}$ $85 \%(\mathrm{~W} / \mathrm{V})$ phosphoric acid was added. The resulting solution was diluted to a final volume of 1 liter. Sample solution $(50 \mu 1)$ or for preparation of standard curve $50 \mu 1$ of serial concentrations containing 10 to $100 \mu \mathrm{g}$ bovine serum albumin were pipetted into test tubes. The volume in the test tube was modified to $1 \mathrm{ml}$ with phosphate buffer $(0.1 \mathrm{M}, \mathrm{pH} 6.6)$. Five $\mathrm{ml}$ of protein reagent were added to the test tube and the contents were mixed. The absorbance at $595 \mathrm{~nm}$ was measured after 2 min compared with blank. 


\section{Phosphorus (P) Determination :}

To determine the phosphate ion a commercial kit of Quimica Clinica Applicada S.A. (Spain) was used. P reacts with molybdate to produce phosphor-molybdate, which is finally reduced to a molybdenum blue which is photometrically measured at650 $\mathrm{nm}$. Zero adjustment was against reagent blank, and results obtained after comparison with a reference standard (conc. $4 \%$ ) .

\section{Nitrogen (N) Determination:} digestion.

The nitrogen in protein is converted into ammonium sulphate by $\mathrm{H} 2 \mathrm{so} 4$ during

This salt was collected in a boric acid solution and titrated against standard acid. Since1 $\mathrm{ml}$ of $0.1 \mathrm{~N}$ acid is equivalent to $1.4 \mathrm{mg} \mathrm{N}$, the calculation is made to arrive at the nitrogen content of the sample. as described by Jackson(1973).

\section{Potassium (K) Determination:}

Ions measurements were made on a radiometer FLM3 flame photometer as described by Amin and El-Halafawy (2001/2002). The standard solution contained sodium chloride $(14 \pm 1.4 \mathrm{mmol} / \mathrm{L})$ stored at room temperature. Zero adjustments were against blank prepared by adding $5 \mathrm{ml}$ of concentrated lithium chloride $(300 \pm 5 \mathrm{mmol} / \mathrm{L})$ to $500 \mathrm{ml}$ of distilled water.

\section{Calcium (Ca) Determination:}

Calcium ion was determined using the Bio-analytics kit (email: bioanlab@bellsouth .net .Palm city, USA). Calcium reacts with cresophthalein in an alkaline medium to form a colored complex. The color developed has a maximum absorbance at $570 \mathrm{~nm}$ and is proportional to the calcium concentration in the sample. Measurement was against reagent blank and compared to calcium standard (10 $\mathrm{mg} / \mathrm{dl})$.

\section{Statistical Analysis:}

The statistical analysis (ANOVA) of the obtained results was performed using SAS program (SAS Institute, 2006).

\section{RESULTS AND DISCUSSION}

\section{Survey Study:}

The obtained data in Table (1) showed that the tetranychid mite, Oligonychus afrasiaticus appeared to infest the date palm fruits in New-valley, Giza, and Marsa Matruh Governorates only and disappeared from the different locations (El-Menofia, El-Sharkia, and El-Behira) governorates. From the same obtained data it was observed that the mite, $O$. afrasiaticus infested Barhi Variety (Fresh) with a rare number and on Shark El-Ewinate (New-Valley Governorate) only. On the other hand, Siwi variety (Semi-dry) infested with the tetranychid mite $O$. afrasiaticus on date palm fruits in Baharia Oasis (Giza Governorate), Siwa Oasis (Matruh Governorate) and El-Kharga \&El Dakhla Oasis (New-Valley Governorate) However, during the survey study, it was noticed that Samani and Zaghloul (Fresh varieties) did not infest with $O$. afrasiaticus during this study.

The first report of Oligonychus spp. As date palm common pests were in Kharga oasis on Siwi semi-dry Variety (Saleh and Hossny, 1979). O. afrasiaticus was proved that this mite associated with palm trees in the North and South Sini Peninsula (El-Kady, 1997). O. californicus was documented on date palm with a high population as a serious pest allover Egypt (El-Halawany et al., 2001). Also, this pest was reported from Giza and Sohag Governorates as mite species associated with two varieties of the date palm, including their abundance on Zaghloul and Siwi Fresh \& semi-dry varieties (El-Sanady and Mohamed, 2013).

The current study and others are very important to scout periodically and to make an extensive survey for this pest of such economic importance to date palm trees and even on 
wild plants to update the more knowledge of the animal fauna and this is helpful in predicting its peaks to prevent any unexpected behavior and damage.

Table 1: Occurrence of the tetranychid mites on date palm in Egypt

\begin{tabular}{|l|c|c|c|c|c|}
\hline \multirow{2}{*}{ Locations } & \multicolumn{3}{|c|}{ Date palm varieties } & Remarks \\
\cline { 2 - 6 } & $\begin{array}{r}\text { Siwi } \\
\text { (Semi-dry }\end{array}$ & $\begin{array}{r}\text { Saman } \\
\text { (Fresh) }\end{array}$ & $\begin{array}{r}\text { Zaghlou } \\
\text { (Fresh) }\end{array}$ & $\begin{array}{r}\text { Barhi } \\
\text { (Fresh) }\end{array}$ & \\
\hline $\begin{array}{l}\text { El-Sadat } \\
\text { (El-Menofia Governorate) }\end{array}$ & - & - & - & - & \\
\hline El-Kourin (El-Sharkia Governorate & - & - & - & - & \\
\hline Rashid (El-Beheira Governorate) & - & - & - & - & \\
\hline $\begin{array}{l}\text { Baharia Oasis } \\
\text { (Giza Governorate) }\end{array}$ & + & - & - & - & \\
\hline $\begin{array}{l}\text { Shark El-Ewinate } \\
\text { (New -valley Governorate) }\end{array}$ & - & - & - & + & \\
\hline $\begin{array}{l}\text { Siwa Oasis } \\
\text { (Marsa Matruh Governorate) }\end{array}$ & + & - & - & - & \\
\hline $\begin{array}{l}\text { El-Kharga Oasis } \\
\text { (New -valley Governorate) }\end{array}$ & + & - & - & - & \\
\hline $\begin{array}{l}\text { Dakhla Oasis } \\
\text { (New -valley Governorate) }\end{array}$ & + & - & - & - & \\
\hline
\end{tabular}

\section{Biochemical Analysis:}

From the obtained results, Table (2) it was observed that the protein contents were decreased when the date fruits exposed to $O$. afrasiaticus infestation. The protein contents were 18.6 and $26.37 \mathrm{mg} / \mathrm{gm}$ of date fruits in case of infested and non-infested date fruits, respectively. Also, the results of biochemical analysis of date fruits composition in the same previously mentioned table showed that the highest level of carbohydrates contents (445.0 $\mathrm{mg} / \mathrm{gm}$ ) in date palm fruits devoided $O$. afrasiaticus infestation. The lowest carbohydrates level $(308.0 \mathrm{mg} / \mathrm{gm})$ was found when the date fruits exposed to mite's infestation. Considering the nitrogen contents in the date palm fruits, the obtained data presented in Table (3) indicated that there were obvious differences between the fruits infested with mite individuals and noninfested ones. The nitrogen content of infested date palm fruits was $3.33 \mathrm{ug} / \mathrm{gm}$ of fruits but the recorded level of nitrogen in non-infested fruits was $4.37 \mathrm{ug} / \mathrm{gm}$ of fruits.

Table 2: Effect of mite $O$. afrasiaticus infestation on the protein and carbohydrates contents in date palm fruits *

\begin{tabular}{|c|c|c|c|c|}
\hline \multirow{2}{*}{ Sample } & $\mathbf{R}_{\mathbf{l}}$ & $\mathbf{R}_{\mathbf{2}}$ & $\mathbf{R}_{\mathbf{3}}$ & Mean \pm SD \\
\cline { 2 - 5 } & \multicolumn{5}{|c|}{ Total proteins (mg/gm)* } \\
\hline Infested fruits & 18.0 & 18.0 & 19.8 & $18.6 \pm 1.62$ \\
\hline Control & 22.0 & 28.0 & 29.1 & $26.37 \pm 2.06$ \\
\hline & \multicolumn{5}{|c|}{ Total carbohydrates (mg/gm) } \\
\hline Infested fruits & 300.0 & 291.0 & 333.0 & $308.0 \pm 12.55$ \\
\hline Control & 400 & 465.0 & 470.0 & $445.0 \pm 14.68$ \\
\hline
\end{tabular}

$*=\mathrm{R} 1, \mathrm{R} 2, \mathrm{R} 3=$ three replicates were used 
Also, the same obtained data showed that the lowest content of phosphorus was recorded for the fruits already infested with $O$. afrasiaticus mites $(3.1 \mu \mathrm{g} / \mathrm{gm})$ compared to $7.43 \mu \mathrm{g} / \mathrm{gm}$ in case of non-infested fruits. Data presented in Table (3) revealed that there were slightly significant differences between the potassium contents in the date palm fruits infested with individuals of $O$. afrasiaticus. This content was 7.16 and $7.83 \mu \mathrm{g} / \mathrm{gm}$ of date fruits when the fruits infested with mites and cleared ones, respectively. On the other hand, the results of biochemical analysis of date palm fruit composition in (Table 3) showed that the level of Calcium contents was slightly different $(16.4$ and $16.67 \mu \mathrm{g} / \mathrm{gm})$ in date palm fruits infested and non-infested with mite individuals of $O$. afrasiaticus.

Table 3: Effect of mite $O$. afrasiaticus infestation on the nitrogen, phosphorous, potassium and calcium contents in date palm fruits *

\begin{tabular}{|c|c|c|c|c|}
\hline Sample & R1 & R2 & R3 & Mean N SD \\
\hline & \multicolumn{5}{|c|}{ Nitrogen(ug/gm)* } \\
\hline Infested fruit & 3.1 & 3.5 & 3.41 & $3.33 \pm 1.12$ \\
\hline Control & 4.65 & 4.31 & 4.25 & $4.37 \pm 0.28$ \\
\hline & \multicolumn{5}{|c|}{ Phosphorus (ug/gm) * } \\
\hline Infested fruit & 2.91 & 3 & 3.40 & $3.1 \pm 0.11$ \\
\hline Control & 6.8 & 7.9 & 7.6 & $7.43 \pm 0.35$ \\
\hline & \multicolumn{5}{|c|}{ Potassium (ug/gm) * } \\
\hline Infested fruit & 6.9 & 7 & 7.6 & $7.16 \pm 0.44$ \\
\hline Control & 7.5 & 7.2 & 8.8 & $7.83 \pm 0.85$ \\
\hline & \multicolumn{5}{|c|}{ Calcium (ug/gm) * } \\
\hline Infested fruit & 16.8 & 17.3 & 15.1 & $16.4 \pm 1.13$ \\
\hline Control & 16 & 15.5 & 18.5 & $16.67 \pm 1.11$ \\
\hline
\end{tabular}

$*=\mathrm{R} 1, \mathrm{R} 2, \mathrm{R} 3=$ three replicates were used

Sanad et al., (2017) showed that the dust mite O. afrasiaticus has spread out to promising agricultural expansion areas and this finding sets the alarm of existing his mite as a new potential pest for date palm industry in New Vally governorate.

\section{REFERENCES}

Amin , T.R. and El-Halafawy, N.A. (2001/2002 ).Sodium and potassium ions content of haemolymph in the normal and starved cotton leafworm, Spodoptera littoralis (Boisd.). The Bulletin of the Entomological Society of Egypt, Economic Series,28:4957.

Basshaih, G. (1999): Studies on the occurrence of the date palm dust mite, Oligonychus afrasiaticus (McGregor) (Acari: Tetranychidae) and its natural enemies on different date palm varieties in Wadi Hadramout. Master of Science Thesis, Faculty of Agriculture., Aden - University, $55 \mathrm{pp}$.

Bekheet, S.A. and El-Sharabasy, S.F. (2015): Date palm status and perspective in Egypt. In : Date palm Genetic Resources an d Utilization, Vol. 1: Africa and Americas edit by Al-Khayri, Shri Mohan and Jain Dennis V. Johnson 454 pp Springer, Dordrecht, Heidelberg New York, London.

Ben Chaaban, S. and Chermiti, B.(2009): Characteristics of date fruit and its influence on population dynamics of Oligonychus afrasiaticus in the southern of Tunisia. Acarologia, 49(1-2):29-37. 
Ben Chaaban, S. B.; Chermiti, B. and Kreiter, S. (2017): Comparative demography of the spider mite, Oligonychus afrasiaticus, on four date palm varieties in Southwestern Tunisia. Journal of Insect Science, 11: 136.

Bradford, M.M. (I976). A rapid and sensitive method for the quantitation of microgram quantities of proteins utilizing the principle of protein-dye binding. Analytical. Biochemistry, 72:248-254.

Central Administration for Agricultural Extension, Egypt. (2001): Date palm. Bulletin No. 710, 2001, Ministry of Agriculture and Land Reclamation (in Arabic). Cairo, Egypt.

Chao, C. and Krueger, R. (2007): The date palm (Phoenix dactylifera L.): Overview of Biology, Uses and Cultivation, Horticultural. Science, 42 (5): 1077-1082.

Crompton,M. and Birt, L.M.(1967).changes in the amounts of carbohydrates, phosphagen, and related compounds during the metamorphosis of the blowfly, Lucilia cuprina. Journal of Insect Physiology, 13:1575-1595.

Dubios,M.;Gilles,K.A.;Hamilton,J.K.;Rebers,P.A.andSmith,F.(1956).Colorimetric method for determination of sugars and related substances. Analytical. Biochemistry, 28:350-356.

El Hadrami, I. and El Hadrami, A. (2009): Breeding date palm. In: Jain S.M. and P.M. Priyadarshan (Eds.) Breeding Plantation Tree Crops, Springer, New York. pp. 191216.

El-Halawany, A.S., Sanad A.S. and Rakha, M. A. (2017): Field evaluation of date palm dust mite, Oligonychus afrasiaticus (McGregor) control on date palm trees in New Valley Governorate of Egypt. Egyptian Academic Journal of Biological Sciences (F.Toxicology and pest control), Vol. 9 (3): 129-134.

El-Halawany, M. E.; Abdel-Samad, M. A. and El-Naggar, M. E. (2001): Mites inhabiting date palms. In: Second International Conference on Date Palms, Al-Ain,United Arab Emirates : pp. 366-373.

El-Kady, G.A. (1997): Mites associated with date palm trees in North and South Sini Peninsula. $7^{\text {th }}$ Nat. Conf. of Pest. and Dis.of vegetables and Fruits in Egypt, pp. 789806.

El-Sanady.M.A. and Mohameed A.A. (2013): Biodiversity and seasonal abundance of mites associated with two varities of date palm n Giza and Sohag Governorates, Egypt. Acaraines, 7:57-62.

El-Shafie H.A.F.; Abdel-Banat, B.M.A. and Al-Hajhoj, M.R. (2017): Arthropod pest management. Doi:10.1079/PAVSNNR201712049

El-Sohaimy S.A. and Hafez E.E. (2010): Biochemical and Nutritional Characterizations of date palm fruits (Phoenix dactylifera L.). Journal of Applied Sciences Research, 6 (8): 1060-1067.

Elwan, A. A. (2000): Survey of the insect and mite pests associated with date palm trees in Al-Dakhliya region, Sultanate of Oman. Egyptian Journal of Agricultural Research, 78, 653-664.

Jackson, M.L. (1973): Soil Chemical Analysis. Printica-Hall of India, Private Limited, New Delhi.

Mauk, P. A., Perring, T.M. and Shea, T. (2005): Management of Banks grass mite in dates.Topics in Sub-tropics Newsletter, 3, 1-6.

Michael, H.N.; Salib, J.Y. and Eskander, E.F. (2013): Bioactivity of dismetin glycosides isolated from the epicarp of date fruits, Phoenix dactylifera on the biochemical profile of alloxan diabetic male rates. Phytother Research, 27 (5): 699-704.

Ragab, A.R.; El-Kablawy, M.A.; Sheik, B.Y. and Baraka, H.N. (2013):Antioxidant and tissue-protective studies on Ajwa extract dates from Al Madinah Al-Monwara, Suadi Arabia. Journal of Environmental and Analytical Toxicology, 3:1 
Rahmani, A.H.; Salah, M.A.; Habeeb, A.; Babiker, A.Y.; Srikar, S. and Khan, A.A. (2014): Therapeutic effects of date fruits Phoenix dactylifera in the prevention of diseases via modulation of anti-inflammatory, anti-oxidant, and anti-tummer activity. International Journal of Clinical and Experimental Medicine ,7 (3): 483-491.

Saleh, M.R.A. and Hosny, M.M. (1979): Observation on Oligonychus spp. Occurring on date bunches (Accari:Tetranychidae). Ain Shams University, Faculty of Agriculture Research Bulletin , 1014:1-8.

Sanad, A.S.; El-Halawany, A.S.; Abou-Setta, M.M. and El-Khateeeb, H. M. (2017) Partial survey of date palm dust mite, Oligonychus afrasiaticus (McGregorr) in Egypt including Historical Trait. Acaraines, 11:53-55.

Sas Institute Inc., (2006): The SAS system for windows 9.1. SAS.Institute, Cary, NC., U.S.A.

Talhouk A. S. (1991): On the management of the date palm and its arthropod enemies in the Arabian Peninsula. Journal of Applied. Entomology, 111:514-520.

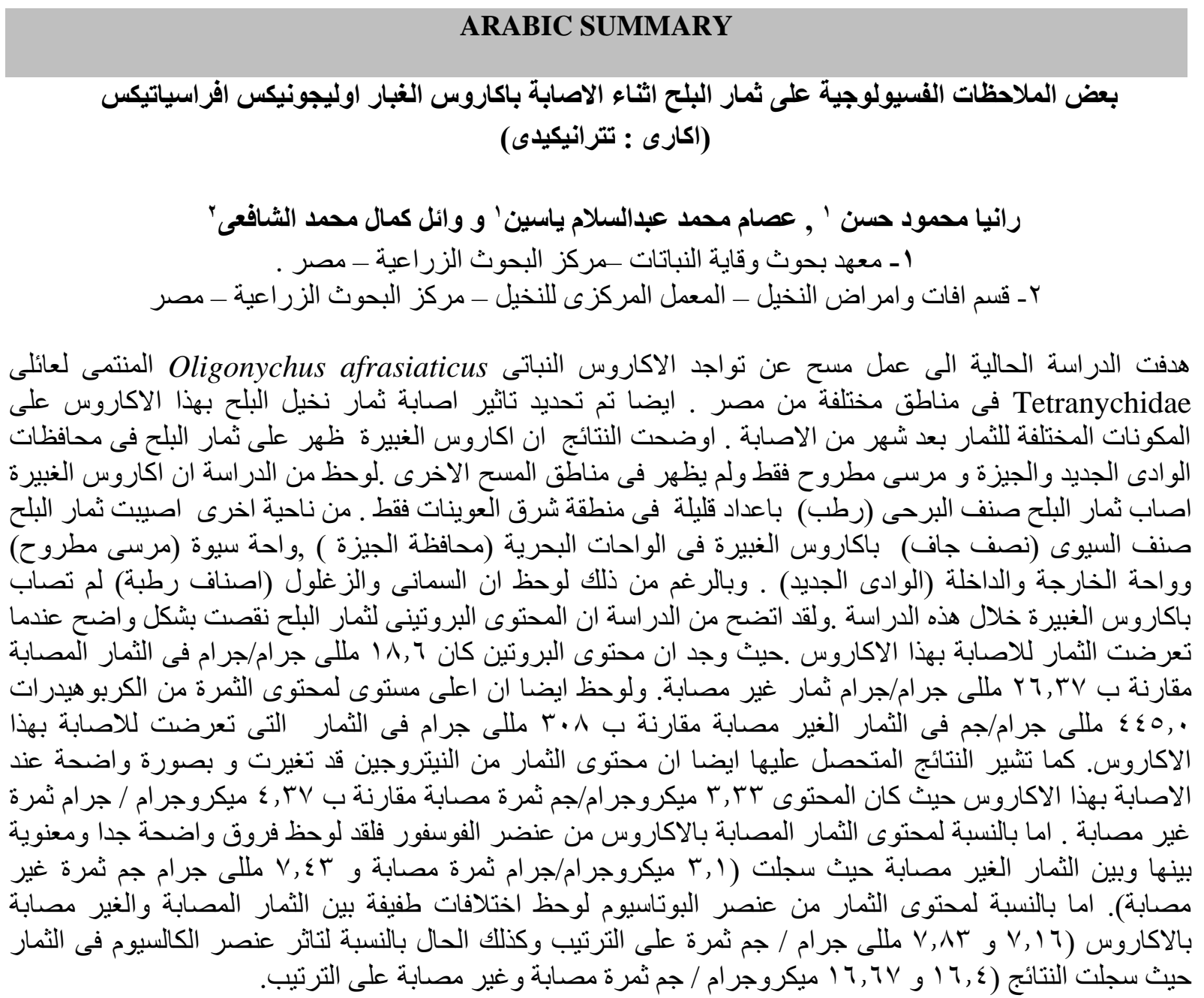

